\section{Ordforklaringer}

PCNSL Iprimary central nervous system lymphoma): Primært lymfom i sentralnervesystemet. Lymfekreft i hjerne, ryggmarg eller øye som ikke viser spredning utenfor sentralnervesystemet.

Genetisk veiledning: En kommunikasjonsprosess som tar for seg menneskelige problemer forbundet med forekomsten av eller risikoen for arvelig sykdom i en familie. Denne prosessen innebærer at en eller flere spesielt utdannede prøver å hjelpe den enkelte og/eller familien med å forstå de medisinske fakta, få oversikt over valgmulighetene som finnes og å tilpasse seg sykdommen.

Se oversikt over doktoravhandlinger i seksjonen Oss imellom på side 1074
Tips oss gjerne om doktoravhandlinger på tidsskriftet@legeforeningen.no

\title{
Lymfomer i sentralnervesystemet
}

Forekomsten av primært lymfom i sentralnervesystemet hos norske pasienter med aids er redusert i perioden 1989-2003, men er økt hos andre. Prognosen er ikke blitt bedre.

Dette viser Ingfrid Salvesen Haldorsen i avhandlingen Primary central nervous system lymphoma in Norway, 1989-2003 Incidence, clinical features, histopathological findings, imaging characteristics, treatment, and outcome in a 15-year national material. Studien er basert på data fra Kreftregisteret.

- I løpet av perioden var det 127 nye til-

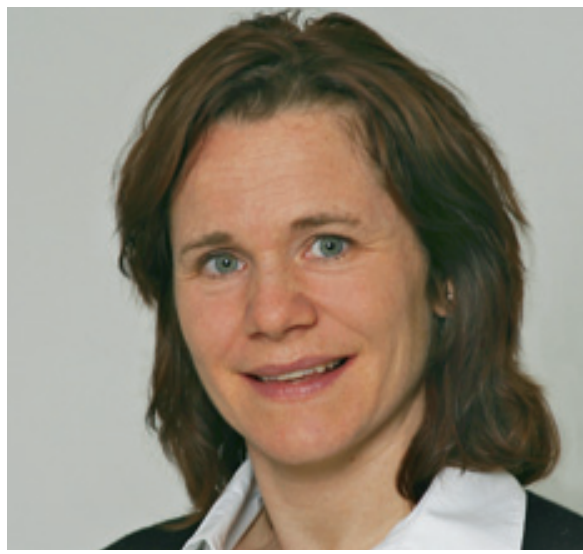

Ingfrid Salvesen Haldorsen. Foto Leif-Arne Markussen, Universitetet i Bergen feller av primært lymfom i sentralnervesystemet i Norge. Selv om behandlingsmulighetene er blitt bedre de siste tiår, var overlevelsen for pasientgruppen uendret, sier Haldorsen.

Forekomsten er spesielt høy hos pasienter med aids. I løpet av livet fikk 5,5\% av aidspasientene i Norge primært lymfom i sentralnervesystemet. Av disse var bare halvparten i live et par måneder etter symptomstart. Overlevelsen for personer uten aids var bedre, halvparten var i live etter sju måneder og $16 \%$ etter fem år. Leveutsiktene var best hos dem under 50 år og hos dem som var i god allmenntilstand.

- Radiologisk diagnostikk avslørte én eller flere svulster i hjernen hos de fleste av pasientene, men hos en del var det ingen funn som kunne gi mistanke om sykdommen. Raskere diagnostikk og tidligere behandling er ønskelig, sier hun.

Haldorsen disputerte for ph.d.-graden ved Universitetet i Bergen 6.2. 2009.

\section{Anne Forus}

anneforu@online.no

Tidsskriftet

\section{Genetisk veiledning ikke uproblematisk}

\section{De fleste som henvises til genetisk veiledning for arvelig kreft takler situasjonen bra. Det betyr ikke at det er uproblematisk for alle.}

Personer som har opphopning av bryst-, eggstokk- eller tykktarmskreft i familien kan henvises til genetisk utredning og veiledning. Cathrine Bjorvatn ved Universitetet $\mathrm{i}$ Bergen ville finne ut hvordan disse menneskene opplever sin situasjon, både før og etter veiledningen. 214 personer besvarte et spørreskjema ved seks ulike tidspunkter før og etter konsultasjonene.

- De fleste som kom til oss hadde det rimelig bra, med få symptomer på angst og depresjon og et moderat nivå av kreftrelatert stress. De fikk det heller ikke verre ett år etter veiledningen, snarere tvert imot. Disse menneskene har stort sett tatt kontakt selv og fremstår som en ressurssterk gruppe - de har høy utdanning, et godt sosialt nettverk og høy mestringsforventning, sier Bjorvatn.

Hun fant imidlertid at $25 \%$, en ikke ubetydelig andel, hadde mer omfattende angst og kreftrelatert stress. Disse hadde mindre sosial støtte og lavere mestringsforventning. Bjorvatn mener dette indikerer at et tilbud om gentest til kvinner med bryst- og eggstokkreft, for å få kunnskap om de har en arvelig variant, bør tenkes nøye igjennom.

- Vi når da ut til en helt annet pasientgruppe enn dem som tar kontakt på egen hånd, og må i så fall passe nøye på, sier hun.

Bjorvatn disputerte for ph.d.-graden 2.4. 2009 med avhandlingen Genetic counseling and hereditary cancera prospective study with emphasis on psychosocial aspects.

\section{Eline Feiring}

eline.feiring@legeforeningen.no

Tidsskriftet 